\title{
Supratentorial Hemangiopericytoma: Case Report
}

\author{
Necati Tatarl,, ${ }^{1}$ Yusuf Emrah Gergin,, Selçuk Özdoğan, \\ Dilek Yavuzer, ${ }^{2}$ Mehmet Tiryaki, ${ }^{1}$ Tufan Hiçdönmez'
}

\author{
'Department of Neurosurgery, \\ Kartal Dr. Lütfi Kırdar Training and \\ Research Hospital, İstanbul, Turkey \\ ${ }^{2}$ Department of Pathology, Kartal \\ Dr. Lütfi Kırdar Training and \\ Research Hospital, İstanbul, Turkey \\ Submitted: 20.10 .2014 \\ Accepted: 23.10 .2014 \\ Correspondence: Necati Tatarlı, \\ Semsi Denizer Cad. E-5 Karayolu \\ Cevizli Mevkii, 34890 Kartal, \\ İstanbul, Turkey \\ E-mail: necatitatarli@gmail.com

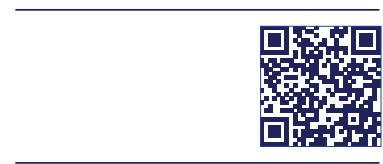 \\ Keywords: Brain tumor; \\ hemangiopericytoma; \\ meningioma; supratentorial.
}

\begin{abstract}
Hemangiopericytoma (HPC) can originate in capillary pericytes of any part of the body. It is a rare vascular tumor, mostly seen in retroperitoneal space, hips, and thighs. Based on clinical and radiological findings, it is difficult to distinguish supratentorial intracranial HPC from meningiomas, Intracranial HPC accounts for $0.4 \%$ of all primary central nervous system (CNS) tumors. The World Health Organization (WHO) classified it as grade 2 tumor, and mesenchymal tumors are characterized as having variable malignant potential. Meningeal HPC is an extremely rare tumor, usually found in supratentorial location. Meningioma should be considered in differential diagnosis. Definitive diagnosis is made with histopathological analysis after surgery. In the present report, clinical and pathological features of a 37-yearold male patient who presented with meningeal HPC are described. This case is presented because of the scarcity of such instances in the literature.
\end{abstract}

\section{INTRODUCTION}

Hemangiopericytoma (HPC) accounts for less than 2\% of soft tissue sarcomas, and it is a vascular tumor more frequently seen in retroperitoneum, hips, and thighs of children. ${ }^{[-3]}$ Intracranial HPC is rare and can have clinical features resembling meningioma. ${ }^{[4]}$ Intracranial HPC accounts for $0.4 \%$ of primary central nervous system (CNS) tumors; it is generally localized in supratentorial region. [2,5] The World Health Organization (WHO) considers it a grade 2 tumor. It is known as mesenchymal tumor with malignant potential. ${ }^{[6]}$

\section{CASE REPORT}

A 37-year-old male patient presented at clinic with comp- laints of progressive headache and generalized tonic-clonic convulsions. Neurological examination was unremarkable. On cranial magnetic resonance imaging (MRI), extracranial mass lesion with peripheral intense edema measuring $42 \times 28 \times 35 \mathrm{~mm}$ that diffusely retained contrast media was seen localized in left frontoparietal junction (Figure la, b). Surgery was performed with initial diagnosis of meningioma Mass was totally excised with its dura. Duraplasty was performed using galea graft. No intra- or postoperative complications developed.

Histopathological examination revealed tumoral hypervascular mass consisting of randomly scattered monotonous cells with round-oval nuclei and thin wall which appear as clefts. Tumoral cells had fine chromatin structure and small nuclei with indistinct cytoplasma contours. No prominent cytological atypia or necrosis was found. A 4/10 
BBA mitosis was detected. On histochemical examination, patchy areas stained with CD34 antibody and B cell lymphoma/leukemia gene-2 (Bcl-2) were found, while epithelial membrane antigen (EMA), and S-100 protein positivity were not observed. Based on these findings, tumor was diagnosed as HPC grade 2 (Figure 2a-c).

Patient later underwent radiotherapy, and in postoperative third year had experienced no disease recurrence.

\section{DISCUSSION}

HPC was first defined by Stout and Murray in 1942, and it has been suggested that HPC may derive from Zimmermann pericytes. ${ }^{[7]}$ Meningeal HPC was first described by Begg and Garret in 1954. ${ }^{[8-10]}$

Meningeal HPCs are generally seen in young people, with equal distribution between genders. ${ }^{\left[{ }^{[I]}\right.}$ Symptoms vary with anatomical location of tumors. Frequently, no calcification is present. Because of adjacency to dura and small size, it resembles meningioma; however, meningioma and HPC are completely different pathologies.

HPC grows gradually and leads a painless course because of its soft tissue involvement. ${ }^{[2]}$ It is usually devoid of any capsule, however encapsulated cases have been also reported. ${ }^{[3,4,7]}$ Microscopic evaluation reveals diffuse reticulin fibers and abundant number of large, well-circumscribed cells with little cytoplasm. ${ }^{[12]}$

In cases with meningeal HPC, generally, surgical excision is the preferred method for both diagnostic and therapeutic purposes. Some cases have responded satisfactorily to postoperative radiotherapy. However, without surgery, pericytoma usually responds poorly to chemotherapy and radiotherapy. ${ }^{[1]}$ Postoperative radiotherapy may be desi-
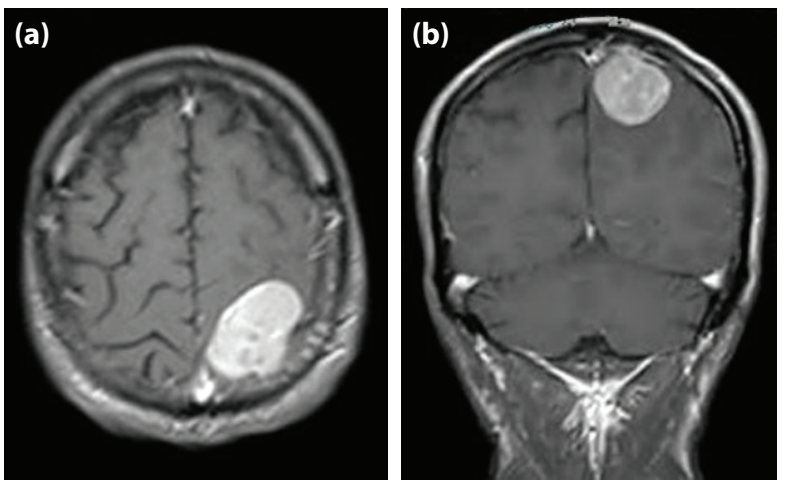

Figure 1. (a) On preoperative T1- weighted contrast-enhanced magnetic resonance examination performed on axial plane, an extraaxial mass measuring $42 \times 28 \times 35 \mathrm{~mm}$ with a diffuse peripheral edema localized on the left frontoparietal junction is seen (b) T1-weighted contrast-enhanced magnetic resonance examination performed on axial plane demonstrates an extraaxial mass lesion.
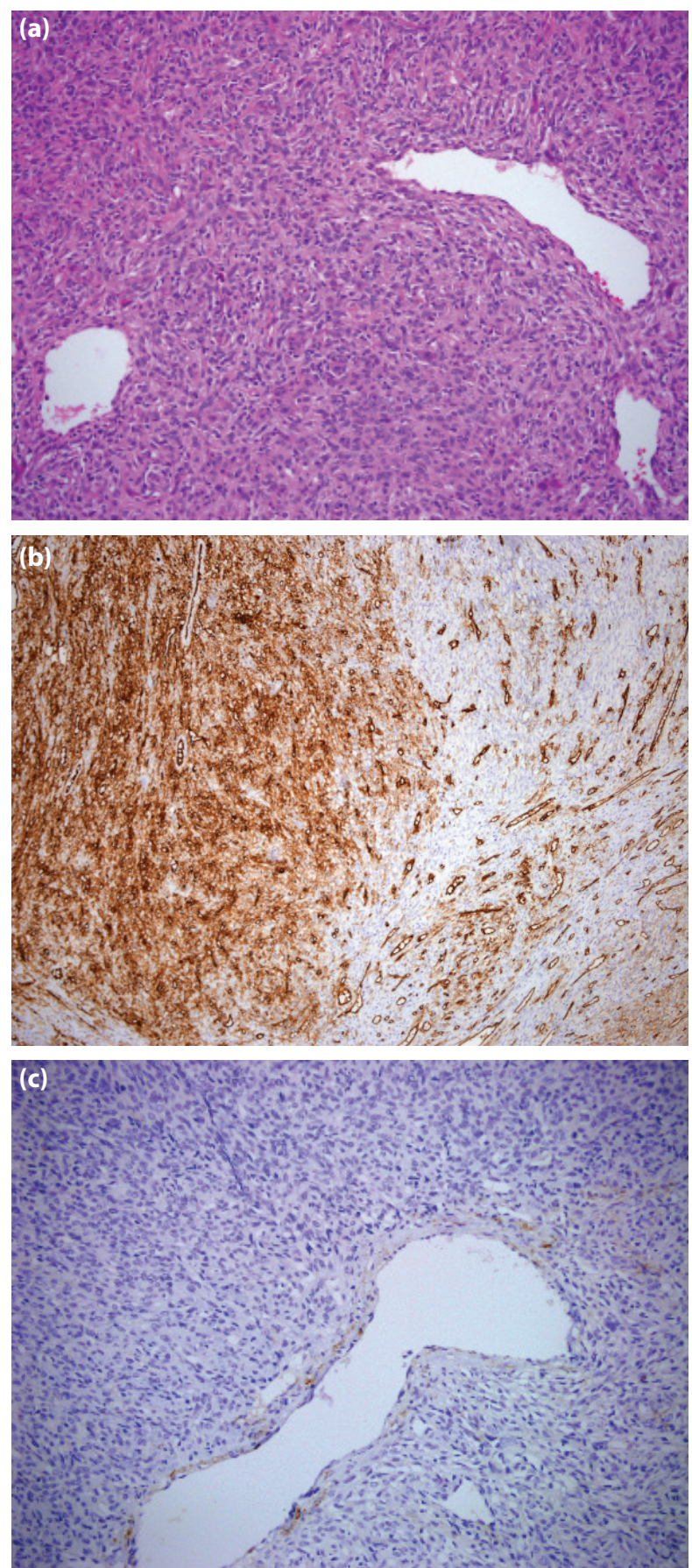

Figure 2. (a) Tumor consists of monotonous cells with hypervascular thin wall, and round-oval nuclei (H-E, x200). (b) Patchy areas of CD34 positivity in tumor cells (immunohistochemistry, $\mathrm{x} 100$ ). (c) Tumor calls were not stained with EMA dye (immunohistochemistry $x 200)$.

rable due to its survival prolongation effects. Pericytoma frequently metastasizes to liver, lungs, and musculoskeletal system. ${ }^{[1]}$ Meningeal HPC is a very rarely seen tumor, generally localized in supratentorial region. Meningioma should be considered in differential diagnosis. Definitive diagnosis is based on postoperative histopathological analyses. 


\section{REFERENCES}

1. Seo I, Kim YS, Kim HS, Kim JH, Lee MK. Hemangiopericytoma of the posterior fossa: a case report and review of the literature. Brain Tumor Res Treat 2013;1:95-8.

2. Radley MG, McDonald JV. Meningeal hemangiopericytoma of the posterior fossa and thoracic spinal epidural space: case report. Neurosurgery 1992;30:446-52.

3. Tian R, Hao S, Hou Z, Bian L, Zhang Y, Wu W, et al. Clinical characteristics and prognostic analysis of recurrent hemangiopericytoma in the central nervous system: a review of 46 cases. J Neurooncol 2013;115:53-9.

4. Tanaka T, Kato N, Arai T, Hasegawa Y, Abe T. Hemangiopericytoma in the trigone of the lateral ventricle. Neurol Med Chir (Tokyo) 2011;51:378-82.

5. Salunke P, Futane S, Gupta K, Vasishta RK. Cerebello-pontine angle hemangiopericytoma: an orphan differential diagnosis. Clin Neurol Neurosurg 2013;115:1184-6.

6. Kaen A, Arrese I, Lagares A, Cabello A, Lobato RD. Haemangiopericytoma presenting with acute intracerebral haemorrhage. Acta
Neurochir (Wien) 2007;149:415-8.

7. Jääskeläinen J, Servo A, Haltia M, Wahlström T, Valtonen S. Intracranial hemangiopericytoma: radiology, surgery, radiotherapy, and outcome in 21 patients. Surg Neurol 1985;23:227-36.

8. Rutkowski MJ, Bloch O, Jian BJ, Chen C, Sughrue ME, Tihan T, et al. Management of recurrent intracranial hemangiopericytoma.J Clin Neurosci 2011;18:1500-4.

9. Das P, Haresh KP, Suri V, Sharma MC, Sharma BS, Sarkar C. Malignant hemangiopericytoma of pituitary fossa. Indian J Pathol Microbiol 2010;53:109-11.

10. Perry A, Scheithauer BW, Nascimento AG. The immunophenotypic spectrum of meningeal hemangiopericytoma: a comparison with fibrous meningioma and solitary fibrous tumor of meninges. Am J Surg Pathol 1997;21:1354-60.

11. Huisman TA, Brandner S, Niggli F, Kacl G, Willi UV, Martin E. Meningeal hemangiopericytoma in childhood. Eur Radiol 2000;10:1073-5.

12. Fredriksson F, Nordborg C, Hallén T, Blomquist E. Haemangiopericytoma presenting with acute intracerebral haemorrhage-a case report and literature review. Acta Oncol 2013;52:753-8.

\section{Supratentorial Hemanjiyoperisitom: Olgu Sunumu}

Hemanjiyoperisitomlar, herhangi bir yerindeki kapiller perisit hücrelerinden kaynaklanırlar. Nadir görülen vasküler tümörler olup, en çok retroperiton, kalça ve uylukta izlenirler. Çoğunlukla supratentoriyal olarak görülen intrakranial hemanjiyoperisitomların, klinik ve radyolojik bulgularla meningiomlardan ayrılması güçtür. Tüm primer santral sinir sistemi tümörlerinin \%0.4’üdürler. Dünya Sağlık Örgütü (DSÖ) tarafından derece II olarak kabul edilmektedirler. Malign potansiyelli mezenkimal tümör olarak bilinirler. Meningeal hemanjiyoperisitomlar çok nadir görülen tümörler olup, genellikle supratentorial olarak yerleşirler. Ayırıcı tanıda meningiyoma dikkat etmek gerekir. Kesin tanı, cerrahi sonrası histopatolojik çalışma ile konmaktadır. Bu yazıda, 37 yaşındaki erkek hastada meningeal hemanjiyoperisitom olgusu sunuldu, klinik ve patolojik özellikleri ele alındı. Literatürde nadir olması nedeniyle bu olgu sunuldu.

Anahtar Sözcükler: Beyin tümörü; hemanjiyoperisitom; meningiyom; supratentorial. 